\title{
9: 34652689-34651894
}

National Cancer Institute

\section{Source}

National Cancer Institute. 9: 34652689-34651894. NCI Thesaurus. Code C41872.

Physical location of CCL27_Gene 